Pages: $1-7$

\title{
PENGARUH PEMBERIAN GUANO WALET TERHADAP PERTUMBUHAN DAN HASIL TANAMAN SAWI (Brassica juncea L.)
}

\author{
Mardhiana $^{1}$, Aditya Murtilaksono ${ }^{2}$, Kapsah $^{3}$ \\ 1,2,3 Jurusan Agroteknologi Fakultas Pertanian Universitas Borneo Tarakan \\ Jalan Amal Lama Nomor 1 Kelurahan Pantai Amal, Kota Tarakan, 77123 \\ Email: mardhiana.ub@gmail.com
}

Receive: 2 September 2018

Accepted: 13 Oktober 2018

\begin{abstract}
North Borneo is one of the largest walet nest producers in Indonesia and can improve the economy of North Borneo. The obstacle faced by walet breeders in North Borneo is walet droppings. Not much research on walet bird droppings, walet droppings is one of the organic fertilizers. The function of organic fertilizer is to increase soil $\mathrm{pH}$ and increase soil fertility. Brassica juncea $\mathrm{L}$ is a commodity planted by North Borneo farmers. North Borneo has low levels of acidity and fertility. This study aims to see the effect of giving guano walet to the growth and yield of Brassica juncea L.. The study design was a one-factor randomized design and was repeated 5 times. Treatments W0: without guano walet (control), W1: guano walet 1.25 tons / ha, W2: walet guano walet 2.5 tons / ha, W3: guano walet 5 tons / ha and W4: guano walet 10 tons / ha. Analysis of the data used is ANOVA (Analysis of Variants) $95 \%$ confidence level to determine the effect of treatment. If there are parameters that influence it is done by Duncan's test of 5\% level. The results of the study were the treatment of W4 gave the highest value and significantly affected the treatment of W0, W1, and W2 but did not significantly affect the treatment of W3 on plant height, leaf number and leaf width parameters. The W4 treatment had the highest average value significantly affected the other treatments on the plant wet weight parameters
\end{abstract}

Key words: Brassica juncea L, organic fertilizer, guano walet, North Borneo

\begin{abstract}
ABSTRAK
Kalimantan Utara merupakan salah satu penghasil sarang burung walet terbesar di Indonesia dan dapat meningkatkan perekonomian Kalimantan Utara. Kendala yang dihadapi oleh peternak burung walet di Kalimantan Utara adalah kotoran burung walet. Belum banyak penelitian tentang kotoran burung walet, kotoran burung walet salah satu pupuk organik. Fungsi pupuk organik adalah meningkatkan $\mathrm{pH}$ tanah dan menambah kesuburan tanah. Sawi merupakan komoditas yang ditanam oleh petani Kalimantan Utara. Kalimantan Utara memiliki tingkat keasaaman dan kesuburan yang rendah. Penelitian ini bertujuan untuk melihat pengaruh pemberian guano walet terhadap pertumbuhan dan hasil tanaman sawi. Rancangan penelitian adalah Rancangan Acak Kelompok satu faktor dan diulang sebanyak 5x. Perlakauan W0 : tanpa guano walet (kontrol), W1 : guano walet 1,25 ton/ha, W2 : guano walet 2,5 ton/ha, W3 : guano walet 5 ton/ha dan W4 : guano walet 10 ton/ha. Analisis data yang digunakan adalah ANOVA (Analisis of Variants) taraf kepercayaan 95\% untuk mengetahui pengaruh perlakuan. Apabila terdapat parameter yang berpengaruh maka dilakukan dengan uji Duncan taraf 5\%. Hasil penelitian adalah perlakukan W4 memberikan nilai tertinggi dan berpengaruh nyata terhadap perlakuan W0, W1, dan W2 tetapi tidak berpengaruh nyata terhadap perlakuan W3 pada parameter tinggi tanaman, jumlah daun dan lebar daun. Perlakuan W4 memiliki nilai rata-rata yang tertinggi berpengaruh nyata terhadap perlakuan lainnya pada paramater berat basah tanaman
\end{abstract}

Kata kunci: sawi (Brassica juncea L.), pupuk organik, guano walet, Kalimantan Utara 


\section{PENDAHULUAN}

Sawi (Brassica juncea L.) termasuk sayuran daari famili cruciferae yang mempunyai nilai ekonomis tinggi. Berdasarkan data perkembangan pertanian tanaman pangan dan hortikultura Kota Tarakan, tanaman sawi adalah tanaman sayuran yang banyak dibudidayakan di Kota Tarakan. Pada tahun 2016 produksi sawi mencapai 3.324,7 ton (Dinas Pertanian Tanaman Pangan dan Hortikultura Kota Tarakan 2016). Permintaan terhadap tanaman sawi selalu meningkat seiring dengan bertambahnya jumlah penduduk dan kesadaran kebutuhan gizi bagi masyarakat. Sebagai upaya untuk memenuhi permintaan konsumen akan sawi maka perlu dilakukan peningkatan produksi tanaman sawi.

Salah satu cara untuk meningkatkan produksi sawi yaitu dengan pemberian pupuk pada tanaman, mengingat bahwa keadaan tanah di Tarakan umumnya memiliki $\mathrm{pH}$ tanah rendah (lahan masam) dan kesuburan tanah kurang. Kendala tersebut dapat menyebabkan pertumbuhan dan hasil tanaman sawi tidak optimal. Pertanian organik merupakan solusi untuk mengatasi masalah tanah di Tarakan

Pertanian organik adalah pertanian yang menerapkan sistem pertanian berkelanjutan karena memanfaatkan sumber daya alam yang ada, bebas dari bahan-bahan kimia dan menggunakan bahan organik. Pupuk organik mempunyai manfaat sebagai media untuk berkembang dan sumber makanan bagi mikroorganisme tanah, memperbaiki permeabilitas tanah, memperbaiki sifat fisik tanah, menambah unsur hara dalam tanah, meningkatkan daya penyerapan dan penyimpanan air pada tanah (Arifin 2007).

Pupuk organik adalah pupuk yang terbuat dari sisa-sisa makhluk hidup yang diolah melalui proses dekomposisi oleh bakteri pengurai (Novizan 2003). Pupuk organik dapat berasal dari kotoran hewan, salah satunya berasal dari kotoran walet yang dalam dunia pertanian disebut pupuk guano. Pupuk guano termasuk dalam pupuk organik yang diperoleh dari kotoran burung liar (walet) dan kelelawar yang menempel pada dinding gua (Wildiyanti, Maya 2009).

Masyarakat Kalimantan Utara saat ini banyak yang membuka usaha penangkaran burung walet. Usaha ini menjanjikan bagi peternak burung walet karena sarang walet harganya mencapai
10-12 juta/Kg di pasaran. Konsekuensi dari usaha penangkaran burung walet adalah menghasilkan limbah, yaitu kotoran burung walet. Limbah dari kotoran burung walet selama ini belum dimanfaatkan oleh para peternak burung walet dan hanya dibuang begitu saja.

Kotoran burung walet sangat berpotensi dijadikan sebagai pupuk organik untuk tanaman. Kandungan yang terdapat dalam kotoran burung walet yaitu nitrogen, fosfor, kalium, kalsium dan magnesium yang sangat bermanfaat terhadap pertumbuhan dan hasil tanaman sawi. Kotoran burung walet mengandung Nitrogen $11.2 \%$, Fosfor $61 \%$, Kalium 2,1\%, (Laboratorium Ilmu Tanah Fakultas Pertanian UBT, 2016). Diperkuat oleh Kandungan nitrogen, fosfor, dan kalium, dengan kadar masing-masing unsur 15\% N, 54\% $\mathrm{P}$ dan 1,7\% K (Sedyarso, 1999).

Isrun (2009), menyatakan bahwa pupuk guano pada setiap peningkatan taraf pupuk $\mathrm{P}$ secara nyata mampu meningkatkan kandungan P-tersedia tanah. Kristanto (2009), Guano yang berada lama dalam jaringan tanah dapat meningkatkan produktivitas tanah dan menyediakan makanan bagi tanaman lebih lama dibandingkan pada pupuk kimia buatan.

Berdasarkan latar belakang tersebut, maka penulis tertarik melakukan penelitian yang mengkaji penggunaan pupuk guano walet pada pertanaman sawi. Apakah pemberian guano walet berpengaruh terhadap pertumbuhan dan hasil tanaman Sawi dan berapakah takaran guano walet yang terbaik terhadap pertumbuhan dan hasil tanaman Sawi

\section{BAHAN DAN METODE}

Penelitian ini dilaksanakan pada tahun 2017 di Kebun Percobaan Fakultas Pertanian Universitas Borneo Tarakan. Alat yang digunakan dalam penelitian ini adalah cangkul, parang, sabit, ember, timbangan, meteran, pisau, oven, kamera dan alat tulis. Bahan yang digunakan dalam penelitian ini adalah benih sawi dan guano walet.

Penelitian ini menggunakan Rancangan Acak Kelompok (RAK), rancangan dengan satu faktor, yaitu dengan perlakuan guano walet, yaitu:

W0 : tanpa guano walet (kontrol)

$\mathrm{W} 1$ : guano walet 1,25 ton/ha

W2: guano walet 2,5 ton/ha 
W3 : guano walet 5 ton/ha

W4 : guano walet 10 ton/ha

Terdapat 5 perlakuan yang diulang sebanyak 5 kali, sehingga diperoleh 25 unit percobaan.

Prosedur Penelitian

1. Pengambilan Guano Walet

Guano walet atau kotoran burung walet diambil langsung dari penangkaran burung walet dan kemudian dijemur sampai kering.

2. Penyemaian

Penyemaian benih sawi dilakukan sebelum pembuatan petak percobaan. Benih yang di semai pada petak persemaian yang berukuran $1 \times 2$ meter dan tinggi $20 \mathrm{~cm}$, dan dicampur dengan pupuk kompos. Media semai atau tempat persemaian sebelum ditanam benih disiram air terlebih dahulu hingga lembab dan dibuat larikan. Jarak antara larikan adalah $5 \mathrm{~cm}$, setelah itu benih disebar pada larikan secara merata pada permukaan media tiap larikan kemudian ditutup tanah.

3. Persiapan lahan dan pengolahan tanah Lahan akan dibersihkan dari gulma dengan menggunakan parang dan sabit, selanjutnya akan dilakukan pengolahan tanah, yaitu membalikan tanah dengan menggunakan cangkul sedalam $30 \mathrm{~cm}$ dan memecahkan bongkahan tanah menjadi halus sehingga kondisi tanah gembur. Setelah pengolahan tanah dilanjutkan dengan pembuatan petak-petak bedengan sesuai dengan ukuran yang telah ditetapkan, yaitu dengan merapikan ukuran panjang dan lebar bedengan dengan menggunakan meteran. Setelah dibersihkan dan dibuat bedengan dengan ukuran lebar $1 \mathrm{~m}$ dan panjang $2 \mathrm{~m}$ untuk ukuran satu bedeng. Jarak antara bedeng $60 \mathrm{~cm}$.

4. Aplikasi Perlakuan

Aplikasi guano walet akan dilakukan tiga hari sebelum tanam. Aplikasi dilakukan dengan memberikan guano walet secara merata pada petak-petak percobaan.

5. Penanaman bibit

Waktu penanaman bibit akan dilakukan dengan cara memindahkan bibit (berumur \pm 2 minggu setelah semai) langsung pada lubang tanah dengan kedalaman kira-kira $5 \mathrm{~cm}$ dengan jarak $20 \mathrm{~cm} \times 50 \mathrm{~cm}$.

\section{Pemeliharaan}

Pemeliharaan yang akan dilakukan meliputi penyiraman, penyiangan dan penggemburan tanah.
7. Panen

Pemanenan tanaman sawi dilakukan pada saat tanaman berusia 28 hari setelah tanam. Pemanenan dilakukan pada pagi hari dengan cara mencabut tanaman sawi.

Pengamatan dilakukan dengan dua parameter yaitu parameter vegetatif dan parameter generatif. Pada parameter vegetatif meliputi tinggi tanaman, jumlah daun, dan lebar daun. Pengamatan dilakukan pada saat tanaman berumur 7, 14, 21, dan 28 HSPT. Paramater generatif yang berupa berat basah tanaman dilakukan pada saat tanaman sawi panen

Analisis data yang digunakan adalah ANOVA (Analisis of Variants) taraf kepercayaan 95\% untuk mengetahui pengaruh perlakuan. Apabila terdapat parameter yang berpengaruh maka dilakukan dengan uji Duncan taraf 5\% untuk mengetahui beda antara perlakuan.

\section{HASIL DAN PEMBAHASAN}

Pada penelitian ini dilakukan pengamatan pemberian pupuk guano walet terhadap tanaman sawi. Parameter pengamatan meliputi tinggi tanaman, lebar daun, jumlah daun dan berat basah tanaman. Data dianalisis menggunakan sidik ragam anova dengan tinggat kepercayaan 95\%, apabila berbeda nyata dilanjutkan dengan uji jarak berganda Duncan. Adapun hasilnya dijelaskan pada Tabel 1.

Tabel 1. Hasil sidik ragam Anova yang dilanjut dengan uji lanjut Dencan

\begin{tabular}{|c|c|c|c|}
\hline No & $\begin{array}{l}\text { Parameter } \\
\text { pengamatan }\end{array}$ & $\begin{array}{l}\text { Hasil uji } \\
\text { F }\end{array}$ & F Tabel \\
\hline 1 & $\begin{array}{lll}\text { Tinggi } & \text { tanaman } & 7 \\
\text { HSPT } & & \end{array}$ & $18.63^{*}$ & 3.01 \\
\hline 2 & $\begin{array}{lll}\text { Tinggi tanaman } & 14 \\
\text { HSPT } & & \end{array}$ & $13.72 *$ & 3.01 \\
\hline 3 & $\begin{array}{lll}\text { Tinggi tanaman } & 21 \\
\text { HSPT } & & \end{array}$ & $7.40^{*}$ & 3.01 \\
\hline 4 & $\begin{array}{l}\text { Tinggi tanaman } 28 \\
\text { HSPT }\end{array}$ & $11.26^{*}$ & 3.01 \\
\hline 5 & Lebar daun 7 HSPT & $17.23^{*}$ & 3.01 \\
\hline 6 & Lebar daun 14 HSPT & $19.65^{*}$ & 3.01 \\
\hline 7 & Lebar daun 21 HSPT & $9.24 *$ & 3.01 \\
\hline
\end{tabular}




\begin{tabular}{|c|c|c|c|}
\hline 8 & Lebar daun 28 HSPT & $10.57 *$ & $\begin{array}{l}\text { 3.01tertinggi namun tidak berpengaruh nyata } \\
\text { terhadap semua perlakuan W3 tetapi berpengaruh }\end{array}$ \\
\hline 9 & Jumlah daun 7 HSPT & $19.11 *$ & 3.01 nyata terhadap perlakuan $\mathrm{W} 2, \mathrm{~W} 1$, dan W0. \\
\hline 10 & HSPT & & $\begin{array}{l}\text { Unsur hara N, P dan K merupakan unsur } \\
3.01_{\text {hara yang sangat dibutuhkan tanaman pada stadia }}\end{array}$ \\
\hline 11 & Jumlah daun $21 \mathrm{HSPT}$ & $7.52 *$ & $\begin{array}{l}3.01 \\
\text { Unsul pertumbuhan terutama pada tinggi tanaman. }\end{array}$ \\
\hline 12 & Jumlah daun $28 \mathrm{HSPT}$ & $12.84 *$ & $\begin{array}{l}\text { 3.01 dapat meningkatkan jumlah bahan organik } \\
\text { sehingga ketersediaan unsur hara dapat }\end{array}$ \\
\hline 13 & Berat basah & $43.59^{*}$ & $\begin{array}{l}\text { 3.0 dimanfaatkan secara optimal untuk mendukur } \\
\text { pertumbuhan tinggi tanaman sawi. }\end{array}$ \\
\hline
\end{tabular}

Keterangan:

* = Berbeda nyata

Tabel 1 menunjukkan bahwa semua parameter pengamatan tanaman sawi berbeda nyata, maka akan dilanjut dengan uji berjarak Duncan.

\section{Tinggi Tanaman}

Berdasarkan hasil sidik ragam anova diketahui bahwa pemberian pupuk guano walet berbeda nyata pada tinggi tanaman sawi pada umur 7, 14, 21, dan 28 HSPT. Untuk mengetaui perlakuan mana yang memberikan pengaruh terhadap tinggi tanaman maka dilanjutkan dengan uji jarak berganda Duncan pada Tabel 2. Tabel 2. Rata-rata Tinggi Tanaman Sawi (cm)

\begin{tabular}{|c|c|c|c|c|}
\hline Perlakuan & $\begin{array}{c}7 \\
\text { HSPT }\end{array}$ & $\begin{array}{c}14 \\
\text { HSPT }\end{array}$ & $\begin{array}{c}21 \\
\text { HSPT }\end{array}$ & $\begin{array}{c}28 \\
\text { HSPT }\end{array}$ \\
\hline W0 & $7.38 \mathrm{a}$ & $8.58 \mathrm{a}$ & $8.62 \mathrm{a}$ & $5.87 \mathrm{a}$ \\
\hline W1 & $9.62 \mathrm{~b}$ & $\begin{array}{c}10.66 \\
\mathrm{~b}\end{array}$ & $\begin{array}{c}10.6 \\
\mathrm{ab}\end{array}$ & $\begin{array}{c}12.36 \\
\mathrm{~b}\end{array}$ \\
\hline W2 & 10.3 & $\begin{array}{c}12.47 \\
\mathrm{c}\end{array}$ & $\begin{array}{c}13.98 \\
\mathrm{bc}\end{array}$ & $\begin{array}{c}16.43 \\
\mathrm{bc}\end{array}$ \\
\hline W3 & $\begin{array}{c}11.05 \\
\mathrm{~d}\end{array}$ & $\begin{array}{c}12.88 \\
\mathrm{~cd}\end{array}$ & $\begin{array}{c}14.12 \\
\mathrm{bc}\end{array}$ & $\begin{array}{c}17.35 \\
\mathrm{bc}\end{array}$ \\
\hline W4 & $\begin{array}{c}11.32 \\
\mathrm{~d}\end{array}$ & $\begin{array}{c}14.36 \\
\mathrm{~d}\end{array}$ & $\begin{array}{c}17.2 \mathrm{c} \\
20.76 \\
\mathrm{c}\end{array}$ \\
\hline
\end{tabular}

Keterangan

W0 : tanpa guano walet (kontrol)

$\mathrm{W} 1$ : guano walet 1,25 ton/ha

W2 : guano walet 2,5 ton/ha

W3 : guano walet 5 ton/ha

W4 : guano walet 10 ton/ha

Tabel 2 Menunjukkan bahwa semua nilai rata-rata tinggi tanaman sawi yang berumur 7, 14, 21, dan 28 HSPT berpengaruh nyata. Semua perlakuan W4 memiliki nilai yang
Unsur hara Nitrogen berfungsi sebagai nitrogen pada pupuk guano walet yang diberikan pertanaman di dalam tanah dan diserap oleh akar tanaman akan menghasilkan tinggi tanaman, jumlah daun dan lebar daun yang lebih besar jika tidak diberikan pupuk guano wallet. Apabila daun kekurangan nitrogen makan warna daun akan menguning dan apabila daun kelebihan nitrogen makan warna daun akan berwarna hijau tua dan daun akan berasa pahit jika dimakan.

Menurut Gardner dkk. (1991) unsur P berperan dalam reaksi fase gelap fotosintesis, respirasi dan berbagai proses metabolisme lainnya. Meningkatnya serapan P tanaman sawi maka pembentukan ATP juga meningkat. Unsur $\mathrm{P}$ yang dihasilkan dalam pembentukan ATP dibutuhkan diantaranya sebagai energi dalam pembelahan sel yang dapat meningkatkan tinggi tanaman.

Unsur $\mathrm{K}$ berperan dalam meningkatkan pertumbuhan jaringan meristem dan sebagai aktivator dalam proses sintesis karbohidrat. Karbohidrat yang dihasilkan akan mempengaruhi meristem untuk pertumbuhan tinggi tanaman.

Diperkuat pendapat Sulistyowati (2011) bahwa pertumbuhan tinggi tanaman disebabkan oleh aktivitas meristem apikal yaitu bagian pucuk tanaman yang aktif membelah sehingga tanaman akan bertambah tinggi. Aktivitas meristem apikal sangat tergantung pada ketersediaan karbohidrat yang diperoleh dari hasil fotosintesis.

\section{Lebar daun}

Berdasarkan hasil sidik ragam anova diketahui bahwa pemberian pupuk guano walet berbeda nyata pada lebar daun tanaman sawi pada umur 7, 14, 21, dan 28 HSPT. Untuk mengetaui perlakuan mana yang memberikan pengaruh terhadap lebar daun tanaman maka dilanjutkan dengan uji jarak berganda Duncan pada Tabel 3.

Tabel 3. Rata-rata Lebar Daun Sawi (cm) 


\begin{tabular}{|c|c|c|c|c|}
\hline Perlakuan & $\begin{array}{c}7 \\
\text { HSPT }\end{array}$ & $\begin{array}{c}14 \\
\text { HSPT }\end{array}$ & $\begin{array}{c}21 \\
\text { HSPT }\end{array}$ & $\begin{array}{c}28 \\
\text { HSPT }\end{array}$ \\
\hline W0 & $2.68 \mathrm{a}$ & $3.61 \mathrm{a}$ & $3.63 \mathrm{a}$ & $4.02 \mathrm{a}$ \\
\hline W1 & $3.90 \mathrm{~b}$ & $4.47 \mathrm{~b}$ & $5.24 \mathrm{~b}$ & $5.88 \mathrm{~b}$ \\
\hline W2 & $4.40 \mathrm{c}$ & $6.4 \mathrm{c}$ & $5.39 \mathrm{~b}$ & $\begin{array}{c}8.21 \\
\mathrm{bc}\end{array}$ \\
\hline W3 & $4.71 \mathrm{~d}$ & $6.75 \mathrm{~d}$ & $\begin{array}{c}5.91 \\
\mathrm{bc}\end{array}$ & $\begin{array}{c}7.91 \\
\mathrm{bc}\end{array}$ \\
\hline W4 & $4.87 \mathrm{~d}$ & $6.91 \mathrm{~d}$ & $7.52 \mathrm{c}$ & $9.20 \mathrm{c}$ \\
\hline
\end{tabular}

Keterangan

W0 : tanpa guano walet (kontrol)

$\mathrm{W} 1$ : guano walet 1,25 ton/ha

W2 : guano walet 2,5 ton/ha

W3 : guano walet 5 ton/ha

W4 : guano walet 10 ton/ha

Tabel 3 Menunjukkan bahwa semua nilai rata-rata lebar daun tanaman sawi yang berumur 7, 14, 21, dan 28 HSPT berpengaruh nyata. Semua perlakuan $\mathrm{W} 4$ memiliki nilai yang tertinggi namun tidak berpengaruh nyata terhadap semua perlakuan W3 tetapi berpengaruh nyata terhadap perlakuan $\mathrm{W} 2, \mathrm{~W} 1$, dan $\mathrm{W} 0$.

Tanaman sawi membutuhkan unsur hara $\mathrm{N}$, P dan $\mathrm{K}$ untuk pertumbuhan pada fase vegetatif seperti lebar daun. Unsur hara $\mathrm{N}$ yang tersedia akan menyebabkan proses fotosintesis serta metabolisme tanaman berjalan baik dan lancar sehingga dapat meningkatkan aktivitas tanaman dalam proses petumbuhan vegetatif tanaman. Hal ini sejalan dengan pernyataan Sugeng (2005) bahwa jika fotosintesis berlangsung dengan baik, maka tanaman akan dapat tumbuh dengan baik serta diikuti dengan peningkatan lebar daun tanaman. Hakim et al. (1986) menyatakan bahwa unsur $\mathrm{N}$ merangsang pembelahan dan pembentukan daun. Fosfor berperan pada perkembangan jaringan meristem dalam memperpanjang jaringan sehingga daun tanaman akan semakin panjang dan lebar, serta akan mempengaruhi lebar daun.

Unsur $\mathrm{N}$ dan $\mathrm{P}$ diperlukan dalam jumlah banyak untuk pembentukan protein, apabila kekurangan $\mathrm{N}$ maka tidak terbentuknya protein sehingga metabolisme dan pertumbuhan tanaman akan terganggu. Kekurangan $\mathrm{K}$ dapat menyebabkan transport ion terganggu karena peran dari unsur hara $\mathrm{K}$ adalah untuk penyeimbang ion di dalam dan di luar sel. Soepardi (1983) menyatakan bahwa akibat kekurangan $\mathrm{K}$ fotosintesis terganggu sehingga pembentukan karbohidrat berkurang dan rendahnya kandungan air pada daun sehingga pertumbuhan dan perkembangan lebar daun terganggu.

\section{Jumlah Daun}

Berdasarkan hasil sidik ragam anova diketahui bahwa pemberian pupuk guano walet berbeda nyata pada jumlah daun tanaman sawi pada umur 7, 14, 21, dan 28 HSPT. Untuk mengetaui perlakuan mana yang memberikan pengaruh terhadap jumlah daun tanaman maka dilanjutkan dengan uji jarak berganda Duncan pada Tabel 4.

Tabel 4. Rata-rata Jumlah Daun Tanaman Sawi (helai)

\begin{tabular}{|c|c|c|c|c|}
\hline Perlakuan & $\begin{array}{c}7 \\
\text { HSPT }\end{array}$ & $\begin{array}{c}14 \\
\text { HSPT }\end{array}$ & $\begin{array}{c}21 \\
\text { HSPT }\end{array}$ & $\begin{array}{c}28 \\
\text { HSPT }\end{array}$ \\
\hline W0 & $6.08 \mathrm{a}$ & $6.53 \mathrm{a}$ & $8.84 \mathrm{a}$ & $7.38 \mathrm{a}$ \\
\hline $\mathrm{W} 1$ & $7.65 \mathrm{~b}$ & $\begin{array}{c}7.93 \\
\mathrm{ab}\end{array}$ & $9.92 \mathrm{~b}$ & $\begin{array}{c}10.66 \\
\mathrm{~b}\end{array}$ \\
\hline $\mathrm{W} 2$ & $8.12 \mathrm{c}$ & $9.09 \mathrm{~b}$ & $\begin{array}{c}10.48 \\
\mathrm{~b}\end{array}$ & $11 \mathrm{~b}$ \\
\hline $\mathrm{W} 3$ & $8.44 \mathrm{~d}$ & $\begin{array}{c}9.86 \\
\mathrm{bc}\end{array}$ & $\begin{array}{c}10.58 \\
\mathrm{bc}\end{array}$ & $\begin{array}{c}11.42 \\
\mathrm{bc}\end{array}$ \\
\hline W4 & $8.54 \mathrm{~d}$ & $\begin{array}{c}11.57 \\
\mathrm{c}\end{array}$ & $\begin{array}{c}11.66 \\
\mathrm{c}\end{array}$ & $13.3 \mathrm{c}$ \\
\hline
\end{tabular}

Keterangan

W0 : tanpa guano walet (kontrol)

W1 : guano walet 1,25 ton/ha

$\mathrm{W} 2$ : guano walet 2,5 ton/ha

W3 : guano walet 5 ton/ha

W4 : guano walet 10 ton/ha

Tabel 4 Menunjukkan bahwa semua nilai rata-rata Jumlah daun tanaman sawi yang berumur 7, 14, 21, dan 28 HSPT berpengaruh nyata. Semua perlakuan W4 memiliki nilai yang tertinggi namun tidak berpengaruh nyata terhadap semua perlakuan W3 tetapi berpengaruh nyata terhadap perlakuan W2, W1, dan W0.

Unsur hara $\mathrm{N}$ dari pupuk guano yang tersedia dalam pembentukan daun, dimana unsur $\mathrm{N}$ membantu proses pembelahan dan pembesaran sel yang menyebabkan daun muda lebih cepat mencapai bentuk yang sempurna. Selain disebabkan oleh ketersediaan unsur hara nitrogen pada tanah, unsur $\mathrm{P}$ juga berpengaruh dalam proses pembentukan daun.. Unsur P merupakan bagian penting dalam metabolisme tanaman 
sebagai pembentuk gula fosfat yang dibutuhkan tanaman pada saat fotosintesis. Fotosintesis yang berjalan dengan baik akan menghasilkan fotosintat yang dapat digunakan tanaman untuk pertumbuhan dan perkembangan tanaman. Lakitan (2004), menyatakan bahwa akar, batang dan daun merupakan bagian tanaman yang memanfaatkan fotosintat selama fase vegetatif.

Nyakpa et al. (1988) menyatakan bahwa proses pembentukan daun tidak terlepas dari peranan unsur hara seperti nitrogen dan fosfor yang tersedia bagi tanaman. Kedua unsur hara ini berperan dalam pembentukan sel-sel baru dan komponen utama penyusun senyawa organik dalam tanaman yang mempengaruhi pertumbuhan vegetatif tanaman, khususnya peningkatan jumlah daun.

\section{Berat Basah Tanaman}

Berdasarkan hasil sidik ragam anova diketahui bahwa pemberian pupuk guano walet berbeda nyata pada berat basah tanaman sawi. Untuk mengetaui perlakuan mana yang memberikan pengaruh terhadap berat basah tanaman maka dilanjutkan dengan uji jarak berganda Duncan pada Tabel 5.

Tabel 5. Rata-rata Berat basah Tanaman Sawi (gram)

\begin{tabular}{|c|c|}
\hline Perlakuan & Berat basah (gram) \\
\hline W0 & $24.81 \mathrm{a}$ \\
\hline W1 & $37.15 \mathrm{a}$ \\
\hline W2 & $70.01 \mathrm{~b}$ \\
\hline W3 & $78.36 \mathrm{~b}$ \\
\hline W4 & $173.83 \mathrm{c}$ \\
\hline
\end{tabular}

Keterangan

W0 : tanpa guano walet (kontrol)

$\mathrm{W} 1$ : guano walet 1,25 ton/ha

$\mathrm{W} 2$ : guano walet 2,5 ton/ha

W3 : guano walet 5 ton/ha

W4 : guano walet 10 ton/ha

Tabel 5 Menunjukkan bahwa nilai ratarata berat basah tanaman sawi berpengaruh nyata. Perlakuan W4 memiliki nilai yang tertinggi berpengaruh nyata terhadap semua perlakuan.

Tanaman akan berproduksi optimum apabila unsur hara di dalam tanah mampu diserap dalam jumlah yang cukup. Gardner et al. (1991) menyatakan bahwa dengan unsur hara yang cukup, daun akan berfungsi baik sebagai organ fotosintesis. Laju fotosintesis yang dikendalikan oleh ketersedian unsur hara akan berdampak terhadap pertumbuhan dan produksi suatu tanaman. Unsur hara yang diserap tanaman melalui akar bersama air akan mempengaruhi pertumbuhan seperti tinggi, jumlah daun dan lebar daun. Akumulasi dari tinggi, jumlah daun dan lebar daun akan mempengaruhi dari berat segar tanaman sawi. Semakin baik pertumbuhan tanaman sawi maka semakin meningkat pula berat segar tanaman tersebut. Menurut Lahadassy (2007) untuk mencapai berat basah yang optimal, tanaman masih membutuhkan banyak energi maupun unsur hara agar peningkatan jumlah maupun ukuran sel dapat mencapai optimal dan memungkinkan adanya peningkatan kandungan air tanaman yang optimal pula

\section{KESIMPULAN}

Penelitian yang berjudul pengaruh pemberian guano walet terhadap pertumbuhan dan hasil tanaman sawi dapat disimpulkan bahwa semua nilai rata-rata perlakuan tinggi tanaman, lebar daun dan jumlah daun tanaman yang berumur 7 , 14, 21, dan 28 HSPT berpengaruh nyata. Semua perlakuan W4 dengan tarakan guano walet 10 ton/ha memiliki nilai yang tertinggi namun tidak berpengaruh nyata terhadap semua perlakuan W3 dengan tarakan guano walet 5 ton/ha tetapi berpengaruh nyata terhadap perlakuan W2 dengan tarakan guano walet 2.5 ton/ha, W1 dengan tarakan guano walet 1.25 ton/ha, dan W0 tanpa guano walet. Perlakuan W4 memiliki nilai rata-rata yang tertinggi berpengaruh nyata terhadap perlakuan lainnya pada paramater berat basah tanaman

\section{DAFTAR PUSTAKA}

Arifin Z. 2007. Bokashi (Bahan organik kaya sumber hidup) Malang. Balai Teknologi Pertanian UPTD Petanian.

Gardner, F. P. R. B. Pearce, R. L. Mitchell. 1991. Fisiologi Tanaman Budidaya. Universitas Indonesia Press. Jakarta.

Hakim, N, M. Y. Nyakpa, S. G. Nugroho, A. M. Lubis, M. R. Saul, M. A. Diha, G. B. Hong, dan H. H. Bailey. 1986. Dasar-Dasar Ilmu Tanah. Universitas Lampung. Lampung.

Isrun, 2009. Respons Inceptisol Terhadap Pupuk Guano Dan Pupuk P Serta Pengaruhnya Terhadap Serapan P Tanaman Kacang Tanah Jurnal Agroland. 16(1) : 40-44. Universitas Tadulako. Palu

Kristanto, B. A, R. Kurniantono, D.W. Widjajanto. 2009. "Karakteristik Fotositensis Rumput Gajah (Pennistum Purpureum) Dengan Aplikasi Pupuk Organik Guano”. Seminar Nasional Kebangkitan Peternakan Semarang. Semarang : Universitas Dipenogoro. 
Lahadassy. J. 2007. Pengaruh Dosis Pupuk Organik Padat Daun Gamal terhadap Tanaman Sawi. Jurnal Agrisistem, (3) : 2

Lakitan, B. 2000. Dasar-Dasar Fisiologi Tumbuhan. Raja Grafindo Persada. Jakarta.

Novizan, 2003. Petunjuk Pemupukan Yang Efektif, AgroMedia Pustaka, Jakarta.

Nyakpa, M. Y. A. M. Lubis., M. A Pulungan., A. G. Amrah., Munawar., GO. B Hong dan N. Hakim. 1988. Kesuburan Tanah. Universitas Lampung. Lampung.

Sediyarso, M. 1999. Fosfat Alam Sebagai Bahan Baku dan Pupuk Fosfat. Pusat Penelitian Tanah dan Agroklimat Bogor. Bogor. 82 hal.

Soepardi, G. 1983. Sifat dan Ciri Tanah. Fakultas Pertanian Institut Pertanian Bogor. Bogor.

Sugeng, W. 2005. Kesuburan Tanah (Dasar-Dasar Kesehatan dan Kualitas Tanah). Gava Media. Yogyakarta.

Sulistyowati, H. 2011. Pemberian Bokasi Ampas Sagu Pada Medium Aluvial Untuk Pembibitan Jarak Pagar. J. Tek. Perkebunan \& PSDL (1): 8-12.

Wildiyanti, E, Maya. M. 2009. "Pengaruh Residu Pupuk Kandang Sapi Dan Guano Terhadap Produksi Kedelai (Glycine Max (L) Merr) Panen Muda Dengan Budidaya Organik “. Makalah Seminar Agronomi Dan Hortikultura. Bogor : Institut Pertanian Bogor. 